\title{
КОНЦЕПТУАЛЬНО-КУЛЬТУРОЛОГІЧНА СВОЄРІДНІСТЬ ПОГЛЯДУ ГАВРИЇЛА КОСТЕЛЬНИКА НА РЕЛІГІЮ
}

\section{І.Л. Мірчук}

Українська релігійна філософська думка неодноразово зверталась до проблеми місця релігії в житті суспільства і людини. Не оминув $\dddot{11}$ у своïх богословських та історіософських працях видатний вчений першої половини XX ст. філософ-богослов Гавриїл Костельник. Творчість цього культурного, громадського та церковного діяча вивчена ще надто мало. Щоправда, за останні кілька років розпочато дослідження його творчої спадщини. Зокрема у кількох статтях Наталі Мадей ([4], [5], [6]) висвітлено концепцію української греко-католицької церкви, опрацьовану Г. Костельником, а також заплановано дослідження ряду інших окремих проблем, які порушував Г. Костельник у своїх творах.

Гавриїл Костельник як мислитель формувався в добу тотального захоплення науками, коли була дуже популярною філософія позитивізму й на часі був неопозитивізм. Він розуміє, що довіра до науки сильно розхитало релігійну віру. На початку XX ст. ще не відчувався весь трагізм захоплення наукою, як це відбувається нині. Розвиток природничих наук, наукові відкриття «усунули стіну, яка відділяла людей від Бога, простягли область природничих наук у безкінечні світи, відкрили Всесвіт у ширину й глибину». Вчений переконаний, що «по лінії матеріальних причин не можна дійти до Бога. Треба зійти з тої лінії, й перейти на іншу на лінію духовних явищ, які не можна з'ясувати собі механістичним методом» $[1$, с. 170]. В обширній праці «Християнська апологетика» (1925) Костельник досить глибоко аналізує причини розповсюдження атеїзму в його часи. Загальним фоном, що сприяє цьому явищу, $є$ просвіта, тобто поглиблення освіти широких мас, і розвиток природничих наук. Релігійний світогляд не зазнав на початок XX ст. жодних змін, тоді як механістичний 
матеріалізм має значний прогрес: «Дух часу в Нові часи творить наука з механістичним поясненням світу, з раціональною критикою, з революційністю, філософським суб'єктивізмом та індивідуалізмом. Це витискає релігію з суспільства і з душі особи» [1, с. 168].

Як філософ і мислитель Костельник добре знав, що релігійна віра базується на глибоких, здебільшого фанатичних переконаннях: «Людям лекше відректися вітчизни, національності, ніж релігії, бо в релігії приходить до виразу все, що людина вважає за найглибшу правду та за свою найсвятішу повинність. Людина зростається зі своєю релігією, тому релігія стає, що так скажу, найглибшим «я» людини, без якого вона не може ані уявити собі свого життя. Розстатися зі своєю релігією це для загалу людей таке, як дати собі вирвати своє серце» $[2$, с. 8$]$. Те ж саме можна сказати і про атеїзм як нову віру. Тому він такий небезпечний у суспільстві: «Тільки віра може так засліплювати людей, що вони, хоч зрештою мудрі й учені, в справах своєї віри будуть цілком безкритичні-аж до безумства» $[2$, с. 9]. Дуже небезпечним для суспільства $є$ релігійний фанатизм, який розпалює релігійні війни - це найганебніші й найкривавіші людські вчинки.

3 огляду на це Гавриїл Костельник переконаний, що «релігія є завжди громадською, суспільною справою, хоч державу від церкви відділено», тому держава, яка дійсно дбає про духовне життя своїх громадян, не може байдуже спостерігати те, що діється на «релігійно-церковному полі». Держава прагне володіти душами громадян, але «над душами загалу горожан панує релігія», отже держава не може бути байдужою до «свого партнера, що співволодіє над душами її підданих» [2, с. 13], - так обгрунтовує своє переконання мислитель.

Мислитель намагається збагнути причину релігійної віри, іï, так би мовити, живучості, життєвої необхідності для кожної людини. Він розмірковує і над теологічними обгрунтовуваннями цієї проблеми, і моральними, і психологічними. У християнській теології віра - надприродний Божий дар. Саме поняття «релігія» у перекладі з латинської означає обов'язок, повинність. Отже релігія - це моральний зв'язок людини з Богом. Розумом пізнаємо Бога (комплекс релігійних правд), а волею служимо Богу, тобто пристосовуємо наше життя до пізнання релігійних істин. «Релігійна віра з психологічного становища - це заголовок цілого нашого світогляду. Така вдача нашої душі, що все, що знаємо, й що ми передумали про життя-буття, мусимо звести в якусь остаточну льогічну цілість, мусимо всьому надати якийсь спільний змисл, заголовок - i саме це буде наша віра в релігійному значенні. Це наша найвища орієнтація в житті-бутті, наш найвищий життєвий змисл» $[2$, с. 16$]$. На наш погляд, таке визначення релігійної віри $\epsilon$ глибоко обгрунтованим, бо Костельник виходить з вимог свого часу. Він розуміє, що християнська апологетика повинна стояти на 
тому ж філософському грунті, на якому ведеться боротьба проти християнської релігії. Тому він опрацьовує свій предмет, тобто християнську релігію «з філософічно-критичної сторони, покликуючись на здоровий розум та на факти досвіду» [2, с. 10]. Трактування Гавриїлом Костельником релігійної віри може бути накладене на будь-яку віру - адже це «наша найвища орієнтація в житті-бутті», - і в цьому його філософська глибина.

Мислитель допускає, що під тиском певних обставин людина може сумніватися у правильності своєї віри-релігії, тому може перейти на іншу релігію. Такий перехід передбачає зміни в душі, дуже глибокі зміни, якщо це щира зміна віри, а не «маневри» під тиском політичної кон'юнктури. Життєвий досвід і розуміння світу можуть спричинити зміну релігіїце цілком природно, вважає Костельник. Однак, у життєвій практиці є випадки, що людина починає сумніватися в основах релігії взагалі. Для Костельника це дуже складна проблема, він над нею розмірковує, намагається збагнути мотиви таких сумнівів. Найбільш імовірним мотивом $є$ успіхи природничих наук. Поряд з ними посіяти сумнів у правильності релігійних істин може поведінка церковних діячів, серед яких були і $є$ «негідні одиниці». Християнство само з себе ще не змінює людської природи, не усуває її, тільки доповнює. «Людина має вільну волю, підлягає пристрастям, різним відхиленням, незнанню... Отже, може грішити свідомо й несвідомо» [2, с. 13]. Такі сумніви породжує і поведінка церковних ієрархів, які є дітьми свого часу. Церква не може дозволити наукові дослідження там, де має чітко і однозначно сформульовані догми, вона мусить осудити думки і книги, що суперечать її догмам. Це й відвертає від неї багатьох мислячих людей.

Учений вважає, що церква у наш час не повинна займати в державі провідне, панівне становище. Це шкідливо насамперед для церкви, тому що попередня практика знає багато випадків використовування церкви, iii авторитету для досягнення політичних цілей. I «цезаропапізм», i «папоцезаризм» однаково використовували релігійний фанатизм у політичній боротьбі. «Церква повинна бути свобідна, повинна жити своїм власним духом... Церква повинна бути независима від держави, оскільки лиш се можливе» - такий висновок ученого [3, с. 171].

Найскладнішим питанням тут є те, як владнати незалежність церкви від держави, щоб церква не була покривженою, приниженою, переслідуваною, щоб вона не втратила авторитету в очах вірних. Шлях атеїстів, які цілком заперечуть роль релігії і церкви у суспільстві й державі, Костельник вважає неприйнятним. Багато інтелігентних людей, які засліплені модним атеїзмом, скептицизмом та позитивізмом, не розуміють значення релігії, тому легковажать нею. Проте релігійний світогляд нелегко подолати, він одвіку, природно притаманний людині-вважає Костельник. 
Релігія в найширшому значені слова «се пізнана залежність чоловіка від Абсолюта. В тій залежности кождий чоловік знаходить ся. Ріжниці виступають тільки в понятю Абсолюта. Кождий чоловік мусить «обрахувати ся» 3 Абсолютом» [3, с. 173$]$.

Людина потребує відповіді на кардинальні життєві питання - про сенс життя, про мету життя, звідки цей світ, для чого існує, що чекає світ у майбутньому, як осягнути мету життя та ін. - їх ставить практичне життя і вимагає відповіді. Знайти її допомагає спілкування з Абсолютом, 一 не важливо яким, але він належить до сфери ідеального. Тому Костельник вважає, що «кожна людина мусить визнавати якусь релігію, адже поняття Абсолюта ніколи не базується лише на науці, а переважно на вірі» $[3$, c. 173$]$. «Один релігійний світогляд можна заступити другим релігійним світоглядом, одну релігію другою релігією - але ніколи «наукою» $[3$, c. 174].

Як держава повинна ставитися до релігії, виходячи з того, що вона від природи притаманна людині? Костельник вважає, що політика державної влади щодо релігії повинна базуватися на визнанні психологічних, суспільних та історичних заслуг релігії. Ї̈і не можна так просто відкинути чи заперечити у державі, як і в житті кожного окремого громадянина.

Насамперед, релігія є суттєвим складником людської природи. Вона формує природу людини - розум і почуття, а також волю, покладає на людину певні обов'язки, тобто обмежує їі природну свободу: «Тільки віра в Бога може спричинити внутрішну відвічальність - або що те саме: тільки віра в Бога може спричинити зобов'язання в совісти» [3, с.176]. Воля без зобов'язання є страшною, людина без віри ні перед ким не відповідає за свою сваволю. Це страшно, небезпечно для суспільства. Атеїсти вважають, що таким суддею волі може бути розум, але Костельник стверджує, як $з$ досвіду знаємо, що «сам розум заслабий для нормального панованя над волею та чутям» [3, с.177], коли «Бога немає, то все дозволено». Атеїзм залишає людську душу на поталу сліпій долі, тоді як релігія очищує наші почуття й впорядковує їх. Костельник навіть цитує Г.К. Честертона - одного з новітніх англійських письмеників, який вважає, що людська душа потребує впорядкування, без Бога вона «неначе город, якого не доглядають». «позитивна релігія культивує душу, ставляє для неї ідеали, дає взори, дає силу, зобов'язань» [3, с. 178], «всі сили нашої душі релігія зводить в доцільну гармонію, і підносить душу до найвисшого життя» $[3$, с. 179$]$.

У суспільстві релігія сприяє об'єднанню людей, вона єднає людські душі, у ній люди знаходять силу для самопосвяти, для жертви. Релігія завжди домінувала в суспільстві завдяки християнським ідеалам гуманності, справедливості, прагнення до безконечного, навіть плекала національні ідеали. Християнська релігія здійснила найбільший суспільний перево- 
рот - вона створила нову людину, стала джерелом невичерпного життєвого багатства, ідей поступу, розвитку. Додамо, що християнство розірвало межі замкнутого земного життя, дало людині надію на життя вічне, дало людині-християнину відчуття синівства й благодаті, можливість почуватися Сином Божим, захищеним і зрозумілим у найтяжчих провинах. «Воно дає здорову підставу та провідну ідею, і в нинішніх часах, в часах світової революції, спричиненої війною, християнство дає здорові будуючі ідеї. Суспільна справедливість рівність людей, гуманність і т.д.- се ж виросло з християнської почви. .. $[3$, с. 183]. Якщо в історії були прояви негуманного ставлення до єретиків чи релігійні війни, то джерелом таких негативних явищ $\epsilon$ не релігія, а «спеціальні обставини та суспільні погляди», тобто причина в самих людях. Релігію не можна ігнорувати, тому що вона була джерелом всієї науки, мистецтва й цивілізації, і вона $€$ вершиною науки й культури: «Віра в Бога була історично першим фільозофічним поглядом на світ, а вона $є$ й психольогічно першим фільозофічним поглядом. . . Найвищим і найцікавішим предметом для людської думки навіки останеться Бог зі своїми таємницями» [3, с. 185] «нема і не може бути між людьми сильнішої, більше творчої ідеї, як ідея про Бога» [3, с. 186$]$.

Костельник застерігає, що треба відрізняти вплив релігії від впливу церкви. Церква - це організація, а релігія є їі принципом. Церква найбільш потрібна, найбільш поширена і найбільш могутня народна школа, народний університет з релігійним характером. Саме церква показує, яким могутнім культурним чинником є релігія. У церкві вірним викладають то моральну науку, то догматичну, при цьому зачіпається дещо то з філософії, то з історії, то з літератури, а для простих людей тільки Святе Письмо є книгою і тільки вона притягує їх серця. Церква прив'язує селян міцніше, ніж світська школа, до церкви вони ходять усе своє життя: «Церков в совісти зобов'язує вірних, щоби правильно ходили до церкви. А того ніяка школа зробити не може... Для широких суспільних верств церков $є$ не тільки школою, але заразом театром, музейом, галереєю образів, концертовою салею. Церков се в мініятурі весь культурний світ» $[3$, c. 187].

Крім культурного світу, церква $є$ ще наймогутнішим добровільним товариством. Людина як соціальна істота потребує жити у товаристві, тому церква для кожного вірного дає відчуття єдиної родини, виховує товариське почуття, тому ніщо не може замінити церкви нашому народові, переконаний Костельник. Вона є могутньою організацією в державі, і має «сильне слово в суспільності... Церков - се ареопаг, з котрого найлекше промовити до найширших верств суспільности» [3, с. 188]. Тому й використовують церкву політичні сили для піднесення свого авторитету в суспільстві і впливу на народ. 
3 огляду на таке значення релігії і церкви в суспільстві держава повинна ставитися до церкви з найбільшою симпатією. Державу будують різні суспільні чинники, а релігія серед них $€$ наймогутнішим чинником. Отже, релігію Костельник розцінює як найміцнішу основу держави. Проте, іноді у церкві можуть з'являтися різні естремальні течії, які держава повинна поборювати. Коли влада виступає проти певних церковних організацій, то це не $є$ боротьба проти релігії. Держава може втручатися в церковне життя, якщо церква не відокремлена від держави. Коли держава відокремлена від церкви, то вона не має права втручатися у церковні справи.

Церкву від держави повністю відокремити не можна, тому що релігія «3 природи річи $\epsilon$ суспільним чинником та суспільною проявою» [3, с. 201202]. Церква є могутньою організацією, вона може паралізувати державне життя, тому держава змушена з нею рахуватися. Держава мусить дбати про загальний мир і задоволення всіх громадян-тому повинна примиритися з існуванням і діями церкви, i дати їй певну свободу. Тим більше держава, яка вважає себе демократичною. Республіканський лад-це влада народу, влада повинна іти за бажанням народу, а народ, у своїй масі релігійний, потребує церкви. Демократична влада $\epsilon$ виконавцем волі народу, отже, вона не повинна відмежовуватись від релігії і церкви.

Костельник наводить багато прикладів розподілу обов'язків у суспільстві між державою і церквою, відстоюючи свою точку зору, що кожна з них має свою ділянку впливу, і вони можуть співіснувати, не заважаючи одне одній, а навпаки, доповнюючи себе взаємно на користь і громадянам зокрема, і суспільності в цілому. Розрив між державою і церквою не корисний для держави з тих міркувань, що влада не могла би впливати на вибір найвищої церковної ієрархії, насамперед єпископів. Хоч вибір церковних правителів $є$ справою церкви, все ж держава має право вето. Влада повинна дати церкві повну свободу у розвитку свого життя, навіть у «зносинах з своїми органами, які знаходять ся поза границею даної держави» [3, с. 211]. Костельник, як бачимо, розумів церкву як вселенську організацію, відстоював її свободу. Слід віддати належне його модерним поглядам і широті світогляду - таку свободу він визнає й для атеїстів. Учений добре розуміє, що в демократичному суспільстві вільно й комфортно повинні почуватися всі без винятку громадяни, проте свободу можна визнати лише для тих переконань, які не $є$ шкідливі для суспільства. «Новітній атеїзм, - визнає Костельник, - се могучий рух, виспеціалізована ідеольогія, прикрашена науковими поглядами, і певна річ, що сеї ідеольогії не можна рівнати з марними «переконаннями» якогось обманця чи розбійника. До атеїзму признаються високо образовані, учені люди, які- під суспільно моральним зглядом - ведуть нараз поправне життя...Нікого не можна силувати, щоби змінив свої переконання, наскільки ті переконання не $\epsilon$ 
шкідливі для суспільности» [3, с.212]. Демократична держава змушена толерантно ставитись і до релігії, і до атеїзму, однак не повинна допускати, щоби атеїзм ставав агресивним і нав'язувався релігійним людям. Усі повинні бути рівними у своїх поглядах і жити мирно, визнаючи взаємно права один одного - такий ідеальний лад є справді демократичним, вважає Костельник. До нього повинна прагнути кожна суспільність: «До свободи та рівноправности всіх релігій можна дійти лише в той спосіб, що виходимо з психологічного суспільного становища. Треба належно зрозуміти сей факт, що свого переконання не можна другому чоловікови накидувати силоміць. Кождий чоловік має моральне право придержувати ся та боронити свого переконання все доти, доки своє переконанє уважає правдивим, добрим, святим. Инакше прецінь чоловік був би приневолений поступати проти своєї совісти» [3, с. 216].

Суспільна практика свідчить, що силою не можна здолати жодну релігію, жодну ідеологію. Придушення чи переслідування релігії в супільстві не приносить щастя, а служить джерелом воєн, розбрату, ненависті. Чим більше переслідувана якась релігія, тим більше вона набуває популярності, освячується, набирає внутрішньої енергії, отже, стає сильнішою й впливовішою. Це повинна пам'ятати кожна влада. Виходячи з соціальнопсихологічного стану суспільства, держава повинна надати всім релігіям однакову свободу й однакові права. А при рівних державно-суспільних правах всіх релігій кожна з них може якнайкраще виявити перед людьми свою властиву, справжню вартість та силу до життя.

\section{1 Бібліографія}

[1] Костельник Гавриїл. Христіянська апольогетика. - Львів, 1925.

[2] Костельник Гавриїл. Релігійні фалші нових часів. - Львів, 1937.

[3] Костельник Гавриїл. Границі демократизму. - Львів, 1919.

[4] Мадей Наталя. Гавриїл Костельник і Львівський собор 1946 р. // Вісник Львівського університету. Філософські науки. - 2000. Вип. 1. - С. 128-137.

[5] Мадей Наталя. Релігійно-політичні передумови Львівського собору 1946 року в працях Г. Костельника // Вісник Севастопольського ДТУ. Серія «Філософія». - 2000 р. - С. $73-82$.

[6] Мадей Наталя. Концепція екуменізму в працях українських грекокатолицьких богословів XX ст. // Історія української науки на межі тисячоліть. Зб. наук. пр. - Вип. 2. - Дніпропетровський державний університет. - 2000.- С. 70-76. 